Historic, archived document

Do not assume content reflects current scientific knowledge, policies, or practices. 



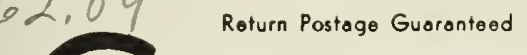 \\ GERMAINS' \\ Horticultural Specialists Since 1871}

6400 E. Washington Blvd. LOS ANGELES 22, CALIFORNIA

\section{Exciting Introductory Offer}

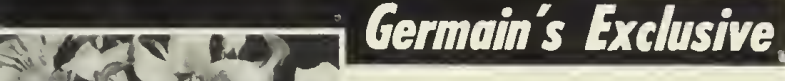

Sec. 34.66 , P. L. Q R.

\section{HYBRID ULY}

OFFERED FOR THE FIRST TIME! Specially selected out of thousinds of TirerCindlestick hybrids for beauty, hardiness and vigol'. Enchanting wax-like texture of this rale hybrid together with thrilling colors makes this new lily a must for your garden. Beautiful in kroups and perfect for June flowering.

No. 5373 SPECIAL PRICE

3 BULbS ONLY $\$ 100$

\begin{tabular}{|c|c|c|c|c|c|}
\hline & \multirow{2}{*}{\multicolumn{5}{|c|}{$\begin{array}{l}\text { With every order, amounting to } \$ 3.00 \text { or over, taken from } \\
\text { items in this folder and sent to us early, we will include, at } \\
\text { no additional cost to you, one or more of the gifts listed } \\
\text { below. } \\
\text { On arders of } \$ 3.00 \text { select any one of the five gifts. } \\
\text { On orders of } \$ 6.00 \text { select two gifts, alike or different. } \\
\text { On orders of } \$ 9.00 \text { select three gifts. } \\
\text { On orders of } \$ 12.00 \text { select four gifts. } \\
\text { On orders of } \$ 15.00 \text { or more select five gifts. } \\
\text { The gift or gifts you select must be written on your order. } \\
\text { They cannot be sent later. }\end{array}$}} \\
\hline & & & & & \\
\hline & \multicolumn{5}{|c|}{ FREE G IFT S } \\
\hline or $\$ 3$ & 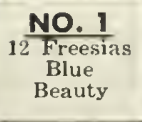 & $\frac{\text { NO. } 2}{12 \text { Oxalis }} \begin{array}{l}\text { Mixed } \\
\text { Colors }\end{array}$ & $\begin{array}{c}\text { NO. } 3 \\
\text { Tulips } \\
\text { Pink } \\
\text { Sensation }\end{array}$ & $\begin{array}{l}\text { NO. } 4 \\
\text { Dutch Iris } \\
\text { Blue } \\
\text { Perfection }\end{array}$ & $\frac{\text { NO. } 5}{6}$ \\
\hline
\end{tabular}

Form 3547 Requested

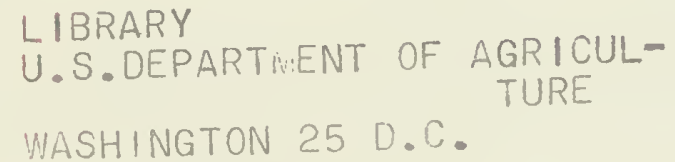

LIBRARY

WASHINGTON 25 D.C.

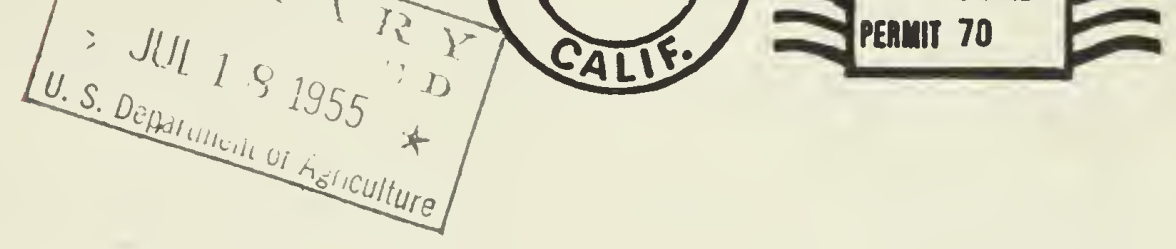

FREE G I F T S 

AMERICA'S WEW FAVORITE CUT FLOWER!

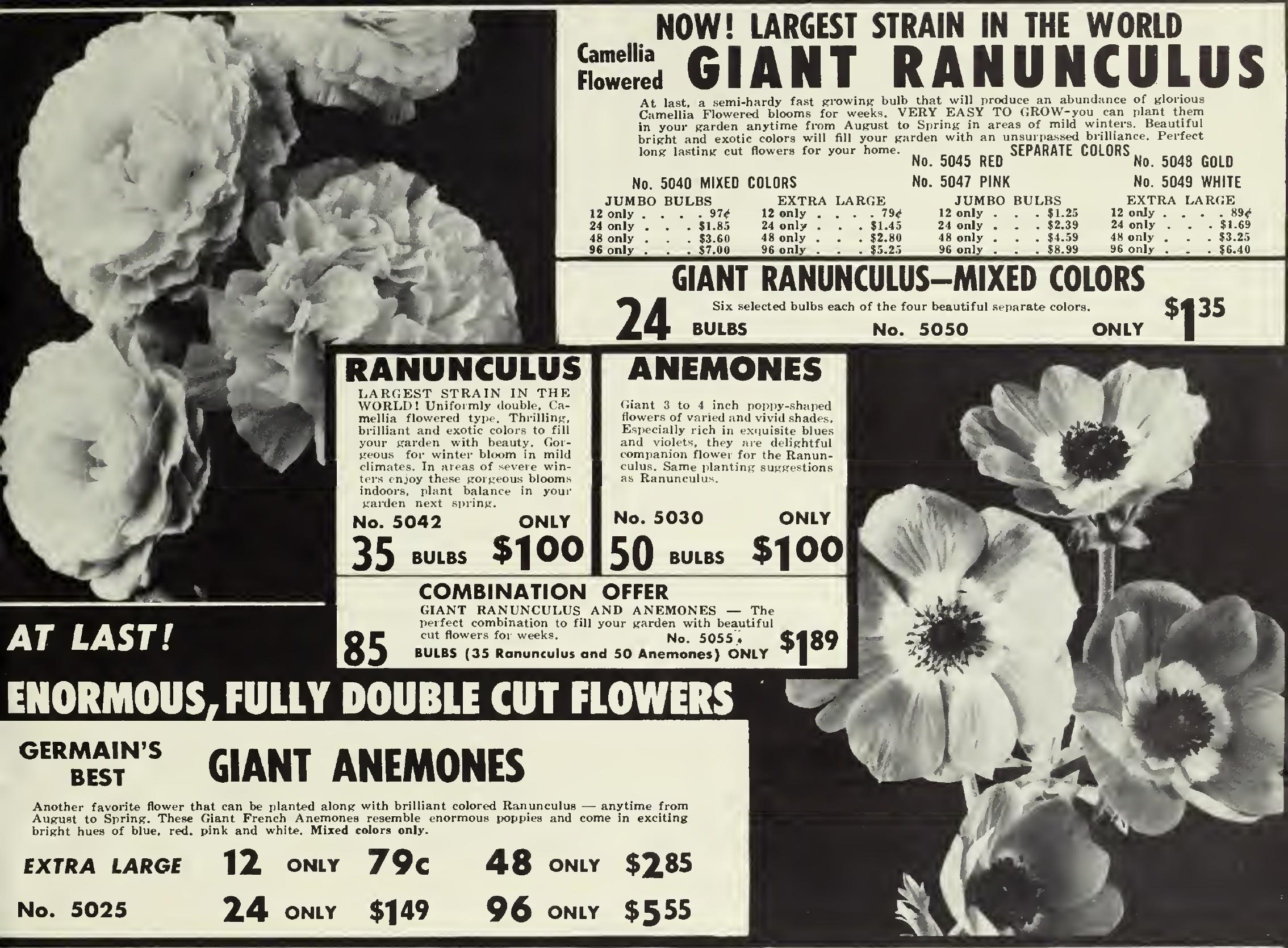

PRECIOUS GARDEN RIGHLIGIIS BABY GLADIOLUS s.tente

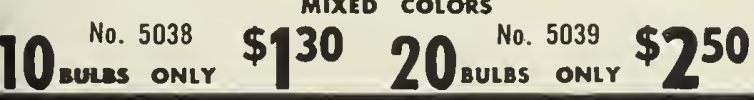

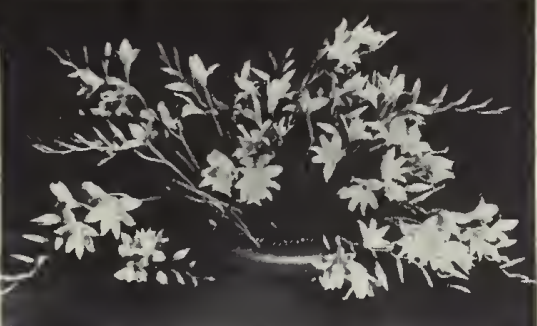

FLOWERING SHAMROCK

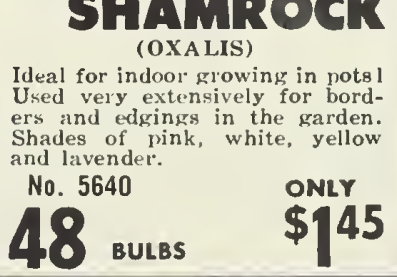

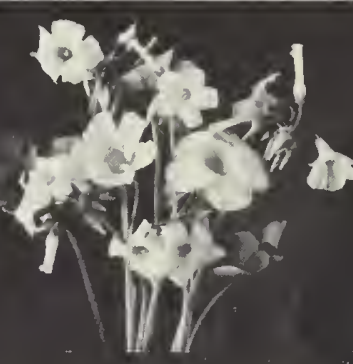

GROWS 4 to 6 FEET TALL ON STURDY STEMS

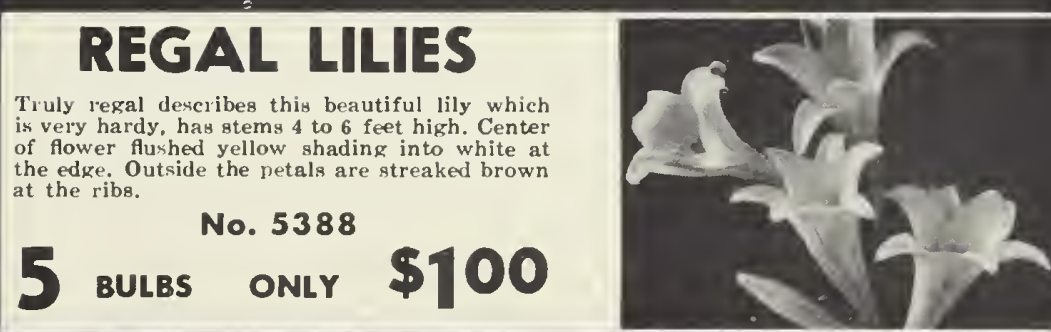

MAGNIFICENT HARDY VARIETY

MIXED COLORS ONLY-No. 5278

20 BULBS ONLY $\$ 100$

40 bulbs ONLY $\$ 189$

60 BULBS

ONLY \$269

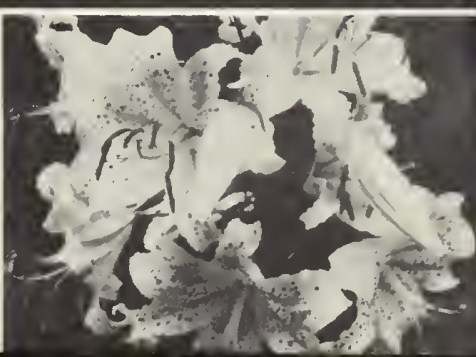

No. 5374

3 wuses onv $\$ 100$ 


\section{WATIOKALLY RECOGHIZED HORTHUI}

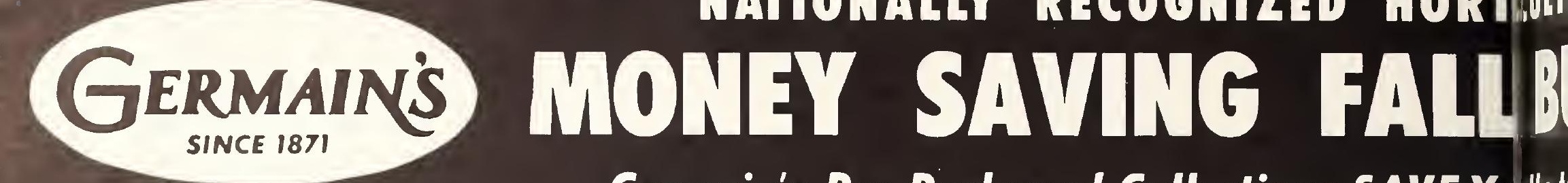

Germain's Pre-Packaged Collections SAVE YoUpt

\section{THE MOST SENSATIONAL TULIPS EVER OFFERD! A GERMAIN'S EXCLUSIVE!! ALL NEW COLLECTION OF Giant TUD \\ ONLY

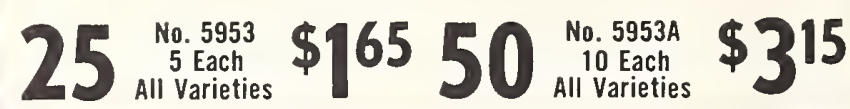

Tulip Combination Offer

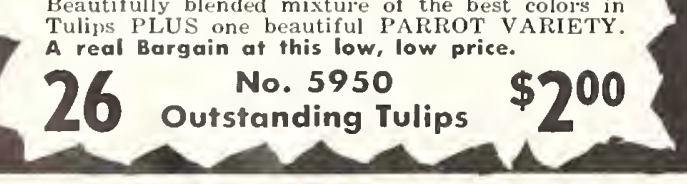

\section{DARWIN TULIPS}

$15 \begin{aligned} & \text { No. } 5955 \\ & \text { BULBS } \ldots . . .\end{aligned}$ GERMAINSA

\section{GIANT PARROT TULIPS}

No. 5805
BULBS
Fill Your Garden ith Fragrantpouk

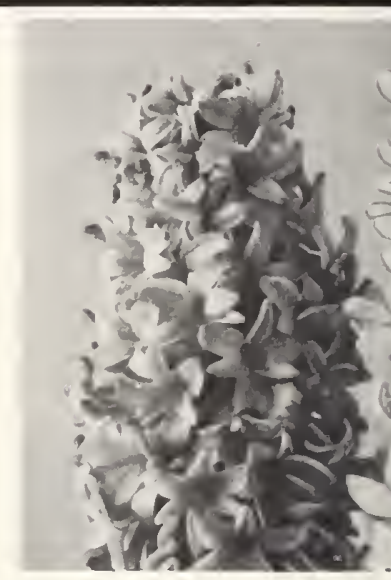

\section{GERMAIN'S FAMOUS}

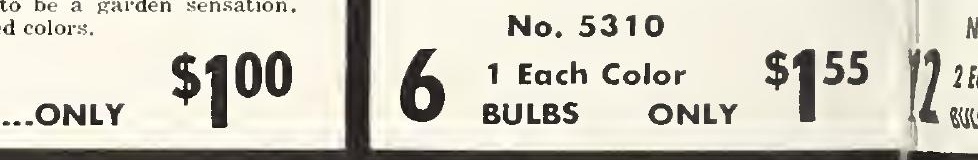

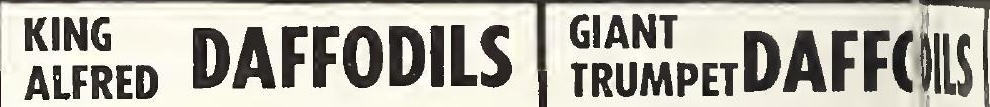
The most beaut

Dutch Hyacinths 


\section{ULTURAL SPECIALISTS}

\section{BULB SPECIALS}

Up to 30\% - ORDER TODAY

In all my years of buying and merchandising flower bulbs I have never in this folder. My trial grounds have produced, beyond doubt, the very highest quality that I have ever seen. Now, due to our enormous production facilities, these marvelous bulbs
are being offered to you at tremendous savings in pre-packaged collections.

I am proud to offer the highest quality to you at a price that makes every single bulb a bargain. Now, you can fill your garden with beauty

Remember-Every bulb you buy from Germain's MUST bloom!

sincerely. OJ MUST bloom!

SPARKLING GOLDEN GARDEN GEMSL

\section{barkling Beauty}

MAGNIFICENT TRUMPET

\section{DAFFODILS}

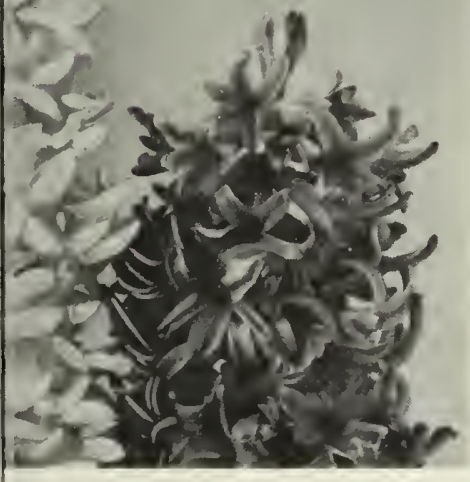

acinths

No. $5310 A$

$12 \begin{gathered}\text { 2ecchch Color } \\ \text { Butbs }\end{gathered}$

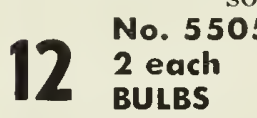

$\$ 195$

\section{No. $5505 \mathrm{~A}$}

24 socks

ONLY $\$ 375$

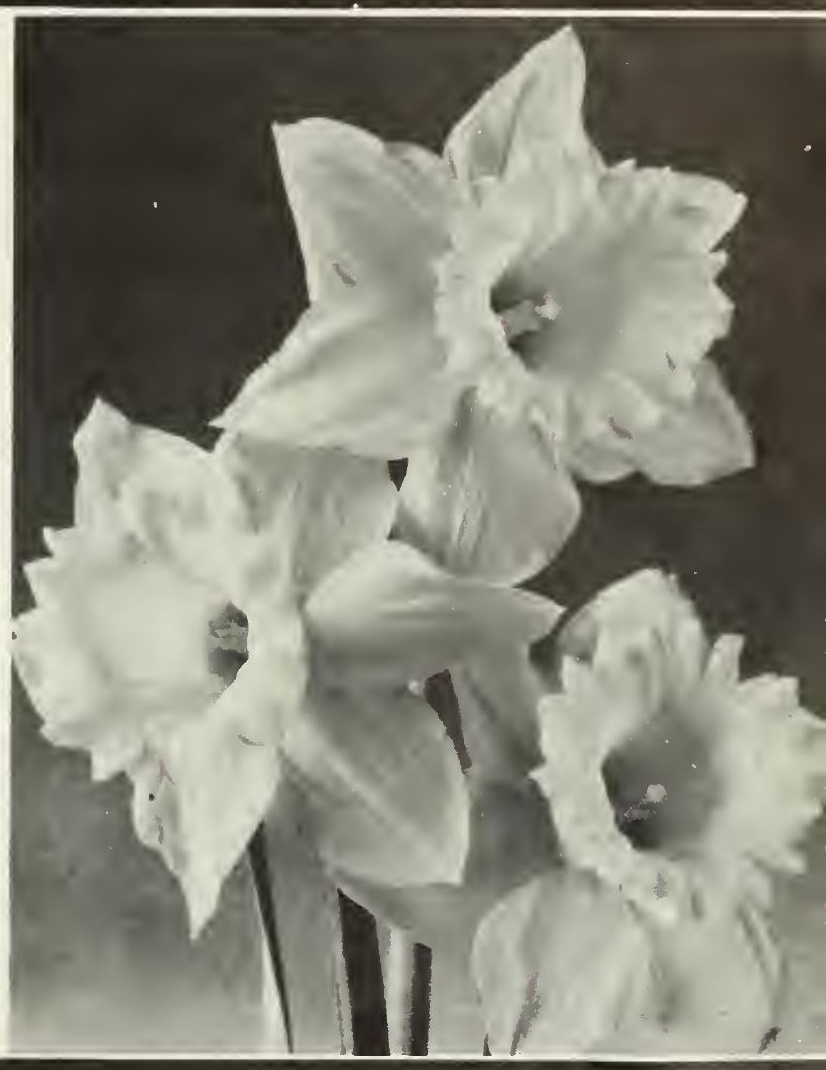

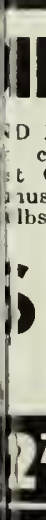

IIS Iris Wedgewood

Large brilliant blue flow splendor for weeks. Forms an exciting

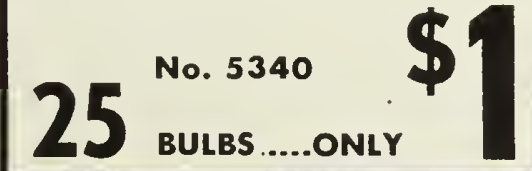

12

$\begin{array}{cc}\text { Any } 6 & \\ \text { Dollar Specials } & \$ \text { ONLY }^{-00}\end{array}$

DUTCH IRIS

MIXED COLORS

\section{IRIS RETICULATA}

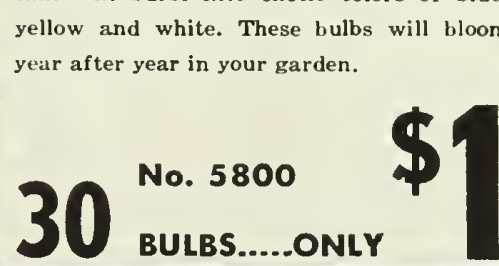

20 No. 5354

\section{THRILLING ORCHID-LIKE BLOOMS - SPECIAL SELECTED BULBS} FOR HOME GARDEN PLANTING

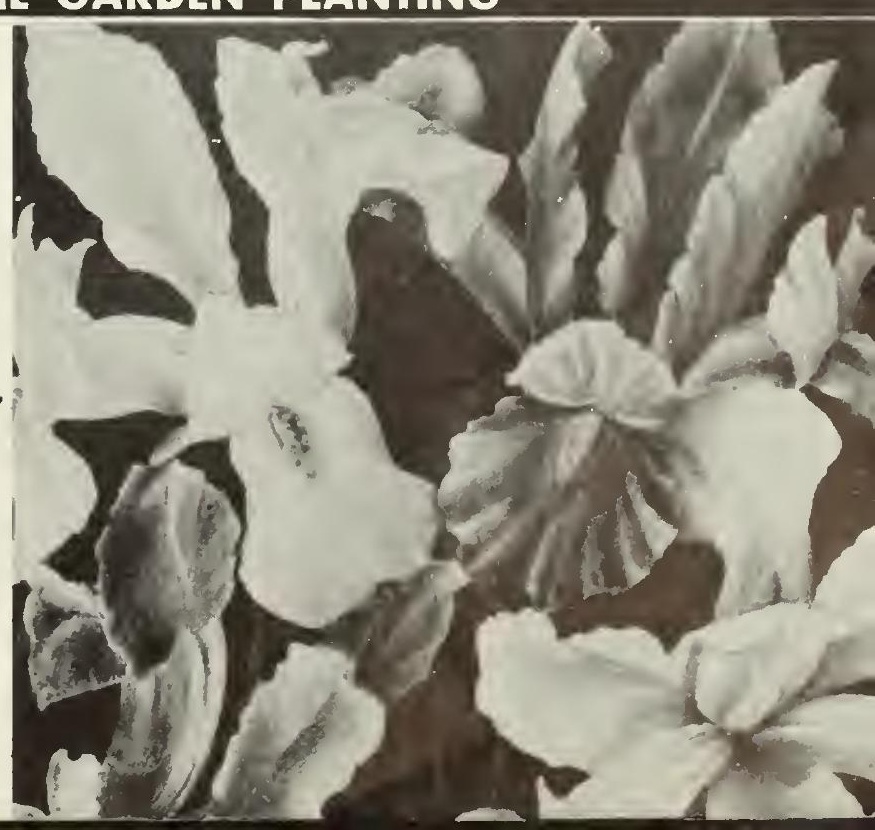

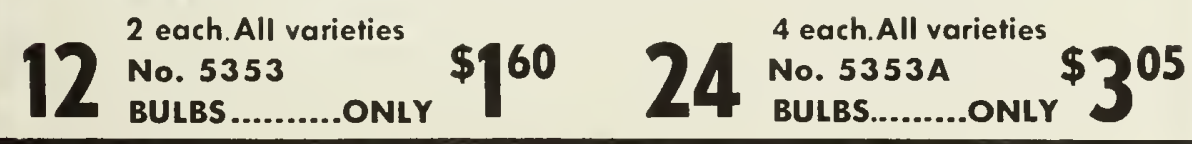

Jamous Offer

BLUE and GOLD GARDEN

4 ,

\begin{abstract}
and produce
Plower, for

with deer

BLUE PEA
\end{abstract}

Dination that you can possibly grow in

dils and 25 Wed
plete your garde

33

No. 5530

12

No. 5351

BULBS........... ONLY

\section{BLUE RIBBON}




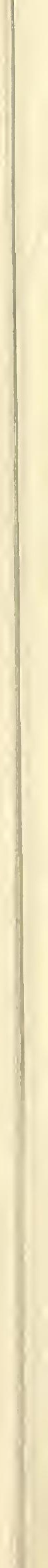




\section{\$1 00 FAL BULB SPEOCIALS \$700}

Easy to Grow

AUTUMN CROCUS

Attractive autumn

flowering Crocus;

flowers rose-lilac with

yellow throat, very freely produced, May be planted

outdoor's or indoors. Planted indoors they bloom in six weeks.

$$
\text { No. } 5196
$$

20 BULBS ONLY $\$ 100$

Dainty Fragrant

\section{GIANT} FREESIAS

Clusters of delightfully fragrant blooms in sparkling color's of the

rainbow. Easy to grow and last a long time.

No. 5222

25

BULBS ONLY

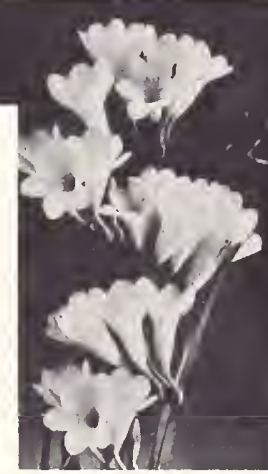
$\$ 100$
GRAPE HYACINTHS (MUSCARI)

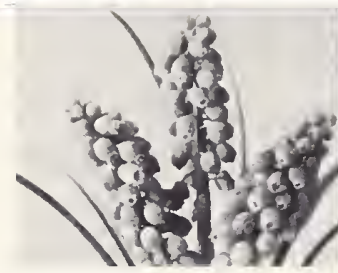

A miniature Hyacinth with much beauty which brings admiration from garden lovers. Vivid sky-blue in color and so small they can be used in so many problem areas to fill-in.

No. 5395

30 BULBS ONLY $\$ 100$ Grow Nyacinths in Water HYACINTH \& VASE SET

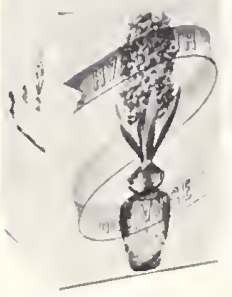

Grow Hyacinths in water in this clear glass vase. One exhibition size Hyacinth hulb, package of charcoal, paler cone and cultural directions. Attractively packaged. A WONDERFUL GIFT

No. B-50 COMPLETE ONIY $\$ 100$
Majestic Garden Jeature CALLA LILIES
PURE WHITE

A true white and one of the lovliest of all lilies. Grows on long sturdy stems. Its green foliage lends contrast of unbelievable beauty either in the garden or in a bouçuet.

No. 5157

3 BULBS ONLY $\$ 100$ Howers in 21 Days LILY of the VALLEY PIPS

Have beautiful blooms in 21 days, giving pleasure to those who want to have an
indoor flower garden. Four of these Pips with a package of bulb fibre.

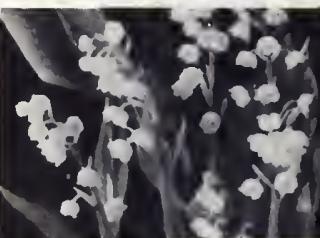

No. $5361 \mathrm{~A}$

4 PIPS PLUS BULB FBRE nHL $\$$

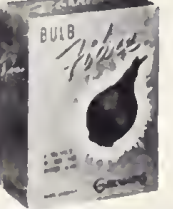

FULL QUART
BULB FIBRE

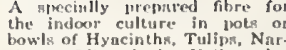

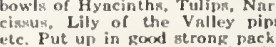
Nc. 5567 ONLY $35 \phi$ 